\title{
Downregulation of Calcitonin Receptor mRNA Expression by Calcitonin during Human Osteoclast-like Cell Differentiation
}

\author{
S. Takahashi, S. Goldring, ${ }^{*}$ M. Katz, S. Hilsenbeck, R. Williams, and G. D. Roodman \\ Veterans Administration Medical Center and the University of Texas Health Science Center, San Antonio, Texas 78284; and \\ * Massachusetts General Hospital, Boston, Massachusetts 02114
}

\begin{abstract}
Calcitonin inhibits both osteoclast formation and bone resorption, and is a primary treatment for patients with hypercalcemia and increased bone turnover. However, the clinical utility of calcitonin is limited because patients become refractory to calcitonin after several days (the calcitonin "escape phenomenon"). The molecular basis for calcitonin "escape" is unclear. To determine the regulatory mechanisms controlling calcitonin receptor (CTR) expression in osteoclasts and their precursors, we treated immature mononuclear precursors for human osteoclast-like multinucleated cells ( $M N C$ ) formed in vitro with $1,25-(\mathrm{OH})_{2} \mathrm{D}_{3}$, to induce their differentiation to committed mononuclear precursors, and mature multinucleated osteoclasts, and used reverse transcriptase (RT)-PCR to assess expression of CTR mRNA in both committed mononuclear precursors and MNC. The PCR fragment produced was cloned and sequenced to confirm that it was derived from CTR mRNA. CTR mRNA expression was detected in mononuclear MNC precursors after $7 \mathrm{~d}$ of $1,25-(\mathrm{OH})_{2} \mathrm{D}_{3}$ treatment. It was also present in osteoclast-like MNC and highly purified giant cells from osteoclastomas, but not in monocytes or macrophage polykaryons formed in vitro. Calcitonin markedly decreased CTR but not actin mRNA expression in giant cells and MNC after $12 \mathrm{~h}$, and removal of calcitonin restored CTR mRNA expression. Similarly, calcitonin decreased calcitonin-induced adenylate cyclase activity. These data suggest: ( $a$ ) downregulation of CTR gene expression by calcitonin may in part explain the calcitonin "escape phenomenon'; and (b) expression of CTR mRNA occurs in mononuclear osteoclast precursors within $7 \mathrm{~d}$ after exposure to 1,25-(OH) $)_{2} \mathrm{D}_{3}$. (J. Clin. Invest. 1995. 95:167-171.) Key words: polymerase chain reaction - calcitonin escape $\cdot$ human marrow cultures $\bullet$ cell differentiation $\bullet$ gene expression
\end{abstract}

\section{Introduction}

Calcitonin receptor $(\mathrm{CTR})^{1}$ expression is regarded as one of the specific markers for osteoclasts that distinguish them from

Address correspondence to Dr. G. David Roodman, Research Service (151), Audie Murphy VA Hospital, 7400 Merton Minter Blvd., San Antonio, TX 78284. Phone: 210-617-5319; FAX: 210-567-4705. 1994

Received for publication 22 April 1994 and in revised form 8 August

1. Abbreviations used in this paper: CTR, calcitonin receptor; MNC, multinucleated cells; RT, reverse transcriptase; TRAP, tartrate-resistant acid phosphatase.

J. Clin. Invest.

(C) The American Society for Clinical Investigation, Inc.

0021-9738/95/01/0167/05 \$2.00

Volume 95, January 1995, 167-171 macrophage polykaryons (1). High affinity CTRs have been detected in osteoclasts from animals and man $(1,2)$, as well as kidney cells $(3)$, some carcinoma cell lines $(4,5)$, and lymphocytes (6), but not on human macrophages (7). During osteoclast differentiation, the appearance of CTR appears to parallel the capacity of mature osteoclasts to resorb bone ( 8 , $9)$. Calcitonin inhibits osteoclastic bone resorption in vitro ( 10 , 11), and has been used clinically to inhibit osteoclastic bone resorption in patients with the hypercalcemia of malignancy (12-14) and with Paget's disease of bone (15). However, patients with cancer become refractory to the effects of calcitonin after several days (the calcitonin "escape phenomenon") (12, 13). The molecular basis for calcitonin "escape" is unclear. Recently, a human CTR cDNA from an ovarian carcinoma cell line was cloned (16), and we have used the reverse transcriptase-polymerase chain reaction (RT-PCR) and specific CTR cDNA primers to assess expression of CTR mRNA in human osteoclast-like multinucleated cells (MNC) and their mononuclear precursors to investigate the regulatory mechanisms controlling CTR expression in osteoclasts and their precursors. We previously have shown that human long-term bone marrow cultures form multinucleated cells that express an osteoclast phenotype (i.e., express CTRs, as detected by ${ }^{125} \mathrm{I}$-salmon calcitonin autoradiography, contract in response to calcitonin and form resorption lacunae on calcified matrices), and used them as a model for osteoclast formation $(7,17-21)$. We have also identified immature mononuclear precursors for these MNC $(7,21)$ and found that treatment of these immature MNC precursors with $1,25-(\mathrm{OH})_{2} \mathrm{D}_{3}$ for $10-14 \mathrm{~d}$ induced expression of CTR on these mononuclear precursors. Therefore, we determined CTR mRNA expression in mononuclear MNC precursors and mature MNC and tested the capacity of calcitonin to regulate CTR mRNA expression and adenylate cyclase activity in these cells and osteoclast-like giant cells from human osteoclastomas.

\section{Methods}

Bone marrow and peripheral blood cells cultures. Cultures of immature mononuclear MNC precursors and osteoclast-like MNC were as previously described (17-21). In brief, CFU-GM colonies were formed by culturing bone marrow nonadherent mononuclear cells in methylcellulose culture with $200 \mathrm{pg} / \mathrm{ml}$ recombinant human granulocyte macrophage CSF (Schering, Plough, NJ) for $7 \mathrm{~d}$. The cultures were then overlaid with $1,25-(\mathrm{OH})_{2} \mathrm{D}_{3} 10^{-8} \mathrm{M}$ (generously provided by Dr. $\mathrm{M}$. Uskokovic, Hoffman LaRoche, Nutley, NJ), and the cultures continued for $10 \mathrm{~d}$. The colonies were then harvested and more differentiated mononuclear MNC precursors were isolated by immune cell panning with the $23 \mathrm{c} 6$ monoclonal antibody (generously provided by Dr. Horton, St. Bartholomew's Hospital, London, UK), which recognizes the vitronectin receptor on osteoclasts and their precursors $(19,22)$. In selected experiments, 23c6-positive mononuclear cells were cultured in $\alpha$-MEM (GIBCO BRL, Grand Island, NY)/20\% FCS (Hyclone Laboratories, Logen, UT) with or without salmon calcitonin $(100 \mathrm{ng} / \mathrm{ml})$ (Rohrer, Fort Washington, PA) for the indicated times. 
Osteoclast-like MNC were formed by culturing bone marrow nonadherent mononuclear cells in $\alpha$-MEM-20\% horse serum with $10^{-8} \mathrm{M}$ $1,25-(\mathrm{OH})_{2} \mathrm{D}_{3}$ for $3 \mathrm{wk}$. MNC were then released with chymopapain treatment $(300 \mathrm{U} / \mathrm{ml})$ (Sigma Chemical Co. St. Louis, MO) followed by gentle scraping with a rubber policeman, and then enriched by panning with the $23 \mathrm{c} 6$ monoclonal antibody. Macrophage polykaryons were formed as previously described (19) by culturing $10^{6}$ peripheral blood mononuclear cells/ml in $\alpha$-MEM-15\% FCS with $10^{-8} \mathrm{M} 1,25$ $(\mathrm{OH})_{2} \mathrm{D}_{3}$ for $3 \mathrm{wk}$. Monocytes were separated from peripheral blood mononuclear cells by adherence to plastic tissue culture dishes overnight at $37^{\circ} \mathrm{C}$ in $\alpha$-MEM-20\% FCS. The adherent cell populations were $>95 \%$ monocytes by Giemsa staining.

Giant cell preparation and culture. Preparation of giant cells from osteoclastomas was as previously described (23). Tissue samples of giant cell tumors were minced and dissociated with collagenase and hyaluronidase (Sigma Chemical Co.), passed through stainless steel wire mesh, and the cell suspension panned with the $23 \mathrm{c} 6$ antibody. The initial cell suspension was composed of $0.1 \%$ giant cells, and the $23 \mathrm{c} 6-$ positive cell fraction was composed of $\sim 50 \%$ giant cells. In some selected experiments, 23c6-positive giant cells were cultured in Iscove's modified Dulbecco's medium (IMDM) -20\% FCS with or without calcitonin $(100 \mathrm{ng} / \mathrm{ml})$ for the indicated times.

Isolation of RNA from pagetic bone. Pagetic bone $(\sim 2 \mathrm{~g})$ was cut into small pieces and ground in liquid nitrogen using a diethylpyrocarbonate water-treated mortar and pestle. The bone material was then collected into a polypropylene tube and extracted with $5 \mathrm{ml}$ RNAzol B reagent (Biotecx Laboratories, Inc., Houston, TX). The insoluble bone particles were further homogenized with a polytron tissue homogenizer for $45 \mathrm{~s}$ at $4^{\circ} \mathrm{C}$. RNA was then isolated from the bone according to the manufacturer's protocol.

Polymerase chain reaction. RNA was extracted from $10^{3}-10^{5}$ cells by the guanidinium thiocyanate- $\mathrm{CsCl}$ method (24). RT-PCR was performed using a GeneAmp RNA/PCR kit (Perkin-Elmer Cetus, Norwalk, CT) with a Perkin-Elmer Cetus DNA thermal cycler according to the manufacturer's protocol for RT-PCR. Briefly, RNA primed with random primers was reverse transcribed using cloned Moloney leukemia virus reverse transcriptase $(2.5 \mathrm{U}), 1 \mathrm{mM}$ of each deoxy-NTP, 50 pmol random hexamer, $1 \mathrm{U}$ RNAse inhibitor in a final volume of $20 \mu \mathrm{l}$. The reaction was run at room temperature for $10 \mathrm{~min}$ followed by raising the temperature to $42^{\circ} \mathrm{C}$ for $30 \mathrm{~min}$ to complete the extension reaction. The reaction mixture was heated to $95^{\circ} \mathrm{C}$ for $5 \mathrm{~min}$ to denature the RNA-cDNA hybrids and quick-chilled on ice. PCR was performed with Taq DNA polymerase with 20 pmol of each primer shown below. Oligonucleotide primers for the human calcitonin receptor were synthesized on a DNA synthesizer (Applied Immune Sciences, Menlo Park, CA). The CTR sequences were: sense (1158-1178) 5'ACTGCTGGCTGAGTGTGGAAA3', antisense (1454-1474) 5'GAAGCAGTAGATGGTCGCAAC3' (16), and were specific for CTR and did not react with other members of this receptor family (data not shown). The cycle profile was as follows: $45 \mathrm{~s}$ at $94^{\circ} \mathrm{C}$ for denaturation, $90 \mathrm{~s}$ at $64^{\circ} \mathrm{C}$ for annealing, and $3 \mathrm{~min}$ at $72^{\circ} \mathrm{C}$ for primer extension for 45 cycles, and finally, a 10 -min extension at $72^{\circ} \mathrm{C}$. PCR products were electrophoresed in $2 \%$ agarose gel and visualized using ethidium bromide. To confirm that the PCR product was derived from CTR mRNA, the product was cloned using a TA cloning kit (Invitrogen, San Diego, CA) and sequenced. For the internal controls, we used RT-PCR of tartrate-resistant acid phosphatase (TRAP) and $\beta$-actin mRNAs. These mRNAs were measured at plateau levels to confirm that the RNA in the samples was not degraded, and thus cannot be used to compare the amounts of the CTR mRNA expressed in these samples. The sequences for those primers were: TRAP, sense (97-120) 5'GCCACCCCTGCCCTGCGCTTTGTA3', antisense (581-602) 5'CTTGAGCCAGGACAGCTGTGTG3' (25); $\beta$-actin, sense (975-994) 5'AGGATGAGAAGGAGATCACT3', antisense (1149-1168) 5'TAGAAGCATTTGCGGTGGAC3' (26).

Adenylate cyclase assay. cAMP production was measured in intact highly purified giant cells or human osteoclast-like MNC $\left(10^{5}\right.$ cells $/$ well) as previously described (27). After culture for the indicated times, cells were washed with $\alpha$-MEM three times, then incubated for $2 \mathrm{~h}$ with
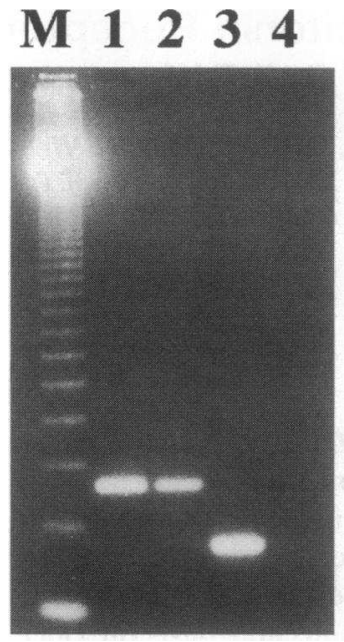

Figure 1. Calcitonin receptor mRNA expression in giant cells from osteoclastomas and RNA isolated from pagetic bone. Lane $M, 123$-bp ladder; lane 1, pagetic bone mRNA with CTR primers; lane 2, 23c6-positive cells from osteoclastomas with CTR primers; lane 3 , Paget bone mRNA with $\beta$-actin primers; lane 4 , water blank with CTR primers. $1 \mu \mathrm{g}$ of RNA extracted from surgical samples of pagetic bone was used in these studies. Preparation of purified giant cells was as described in Methods. RNA from $10^{4}$ giant cells was used for each PCR reaction. Similar results were seen in two independent experiments.

$1 \mathrm{uCi}{ }^{3} \mathrm{H}$-adenine in fresh medium at $37^{\circ} \mathrm{C}$. The cells were then washed twice and incubated with $50 \mu \mathrm{l}$ of DMEM (GIBCO BRL) containing $5 \%$ FCS and $1 \mathrm{mM} 3$-isobutyl-1-methylxanthine (IBMX) (Sigma Chemical Co.). After $5 \mathrm{~min}, 50 \mu \mathrm{l}$ of DMEM with or without $100 \mathrm{ng} / \mathrm{ml} \mathrm{(2}$ $\times 10^{-7} \mathrm{M}$ ) calcitonin were added to each well, and the incubations were continued for an additional $10 \mathrm{~min}$. The incubations were stopped by the addition of $1 \mathrm{ml}$ of trichloroacetic acid at a final concentration of $0.12 \mathrm{M}$, and then neutralized with $20 \mu \mathrm{l}$ of $4 \mathrm{~N} \mathrm{NaOH}$. $20 \mu \mathrm{l}$ of a carrier solution containing cAMP, adenine, adenosine, ATP, and ADP (each $5 \mathrm{mM}$ ) were added, followed by $2,000 \mathrm{cpm}$ of ${ }^{32} \mathrm{P}$-cAMP to monitor cAMP recovery. Cyclic AMP was isolated by the two-column chromatographic method of Salomon et al. (28). cAMP production was measured as counts per minute of ${ }^{3} \mathrm{H}$-cAMP generated from $\left[{ }^{3} \mathrm{H}\right]$ adenine/culture well per 10-min incubation.

Statistical considerations. cAMP $\left({ }^{3} \mathrm{H}\right.$ counts/min $)$ activity, with and without 24-h pretreatment with calcitonin, was measured in a series of five replicated experiments with three or four samples for each treatment group. Logarithms of counts were analyzed using a two-way mixedmodel analysis of variance. The model included a fixed main effect for calcitonin pretreatment and a random effect to adjust for variation in overall cAMP activity between experiments. For display, results are expressed as a proportion of the appropriate control average. Tests were performed at the 5\% level of significance and analysis was carried out using SAS (V6.09; SAS Institute, Cary, NC). The cAMP activity in response to calcitonin without 24-h pretreatment with calcitonin ranged from $1,000-8,000{ }^{3} \mathrm{H}$ counts per minute above background for the five independent experiments.

\section{Results}

Calcitonin receptor $m R N A$ expression in giant cell tumor of bone. Initially, we extracted RNAs from osteoclast-like giant cells from osteoclastomas and surgical bone samples of Paget's patients to determine the capacity of RT-PCR to detect expression of CTR-mRNA from these samples. RNA from $10^{4} 23 \mathrm{c} 6-$ positive giant cells or $1 \mu \mathrm{g}$ of RNA from pagetic bone were used for the PCR reaction. As shown in Fig. 1, we detected a PCR product that was the predicted $317 \mathrm{bp}$ long. The cloned sequence of this product showed complete identity with the predicted sequence of the human CTR CDNA (16), with only $1 \mathrm{bp}$ mismatch on one of the four times it was sequenced. As a control to rule out that we were amplifying genomic DNA rather than detecting expression of CTR mRNA by PCR, we tested genomic DNA from human lymphocytes, but could not amplify the same PCR product (data not shown). Although CTR numbers are variable in these cells, Nicholson et al. (2) 


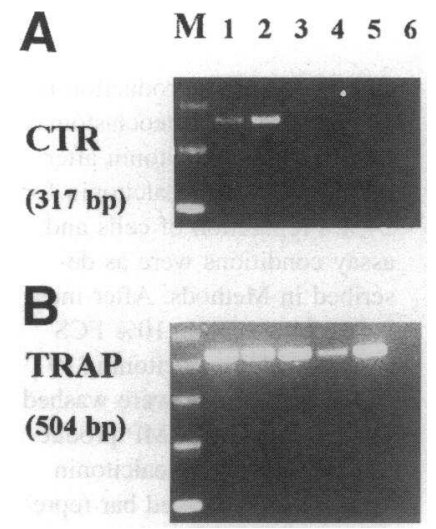

Figure 2. Calcitonin receptor $(A)$ and TRAP $(B)$ mRNA expression in osteoclast-like MNC formed from human bone marrow. Lane $M, 123$-bp ladder; lane 1, 23c6-positive cells from osteoclastomas; lane 2, 23c6positive MNC from bone marrow cultures; lane 3, 23c6-negative cells from bone marrow cultures; lane 4, macrophage polykaryons; lane 5, peripheral blood monocytes; lane 6, no RNA. Bone marrow or peripheral blood mononuclear cells were cultured for $3 \mathrm{wk}$ in the presence of $1,25-(\mathrm{OH})_{2} \mathrm{D}_{3}$ to form multinucleated cells as described in Methods. RNA was extracted from $10^{4}$ cells, reverse transcribed, and amplified with primers for CTR or TRAP. Similar results were seen in four independent experiments.

have previously shown that some giant cells express $>10^{6}$ CTRs per cell.

Calcitonin receptor $m R N A$ expression in osteoclast-like multinucleated cells from human bone marrow. We investigated the expression of CTR mRNA in human osteoclast-like MNC formed in vitro. Human bone marrow nonadherent mononuclear cells $\left(10^{6} / \mathrm{ml}\right)$ were cultured with $10^{-8} \mathrm{M} 1,25-(\mathrm{OH})_{2} \mathrm{D}_{3}$ for 3 wk, then RNA was extracted and amplified from highly enriched 23c6-positive cells. We have previously shown that only the 23c6-positive MNC express CTR (6). Approximately $50 \%$ of MNC formed in the cultures react with the $23 \mathrm{c} 6 \mathrm{mAb}$. We detected the same PCR band from RNA of MNC as that from giant cells and bone (Fig. $2 \mathrm{~A}$ ). The sequence of the CTR clone derived from the MNC PCR product was identical to the predicted CTR sequence. In contrast, we could not detect CTR mRNA expression in macrophage polykaryons formed from peripheral blood mononuclear cells or monocytes (Fig. $2 A$ ), although all three types of cells expressed TRAP mRNA (Fig. $2 B$ ). The expression of TRAP mRNA in monocyte macrophages is consistent with our previous results. In contrast to murine cells, human monocyte-macrophages express TRAP within several hours after adhering to plastic (29).

Calcitonin receptor mRNA expression in mononuclear precursors of human bone marrow-derived osteoclast-like multinucleated cells. We then determined when CTR mRNA was expressed during the differentiation of osteoclast-like MNC from their immature mononuclear precursors. Immature mononuclear precursors were formed in methylcellulose cultures of human bone marrow mononuclear cells treated with rhGM-CSF for 7 $\mathrm{d}$ and then $1,25-(\mathrm{OH})_{2} \mathrm{D}_{3}$ was overlaid on the culture. As shown in Fig. $3 A$, CTR mRNA expression was not detected in these mononuclear cells until $7 \mathrm{~d}$ after addition of $1,25-(\mathrm{OH})_{2} \mathrm{D}_{3}$. In contrast, TRAP mRNA was expressed in immature mononuclear precursors within $3 \mathrm{~h}$ after $1,25-(\mathrm{OH})_{2} \mathrm{D}_{3}$ addition (Fig. $3 B$ ).

Calcitonin inhibition of calcitonin receptor mRNA expression in giant cells from osteoclastomas and human MNC and their mononuclear precursors. We then used this system as a model to investigate the regulation of CTR gene expression by calcitonin in osteoclasts. We tested the effect of calcitonin $\left(10^{-7}\right.$ $\mathrm{M}$ ) on CTR mRNA expression, because osteoclasts lose responsiveness to calcitonin after prolonged treatment $(12,13)$. 23c6-

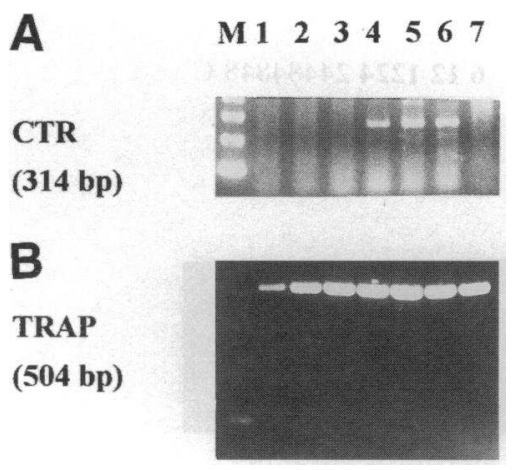

Figure 3. Calcitonin receptor $(A)$ and tartrateresistant acid phosphatase $(B)$ mRNA expression in precursors for osteoclast-like MNC formed in human bone marrow cultures. Lane $M$, 123-bp ladder; RNA from immature $\mathrm{MNC}$ precursors (CFU-GMderived colonies) at (lane 1) time 0; (lane 2) $3 \mathrm{~d}$ after addition of 1,25 $(\mathrm{OH})_{2} \mathrm{D}_{3}$; (lane 3) after $5 \mathrm{~d}$ of 1,25- $(\mathrm{OH})_{2} \mathrm{D}_{3}$ treatment; (lane 4 ) after $7 \mathrm{~d}$ of $1,25-(\mathrm{OH})_{2} \mathrm{D}_{3}$ treatment; (lane 5) after $10 \mathrm{~d}$ of $1,25-(\mathrm{OH})_{2} \mathrm{D}_{3}$ treatment; (lane 6) RNA from the 23c6-positive fraction of CFU-GM-derived cells after $14 \mathrm{~d}$ of 1,25-(OH $)_{2} \mathrm{D}_{3}$ treatment; and (lane 7) RNA from 23c6-negative fraction of CFU-GM-derived cells after $14 \mathrm{~d}$ of $1,25-(\mathrm{OH})_{2} \mathrm{D}_{3}$ treatment. Cell preparation was as described in Methods. RNA was extracted from $10^{4}$ cells, reverse transcribed, and amplified with the primers for CTR or TRAP. Similar results were seen in four independent experiments.

positive giant cells from osteoclastomas were incubated with or without calcitonin, and CTR mRNA expression was determined (Fig. $4 \mathrm{~A}$ ). CTR mRNA expression was not detected after 12 $\mathrm{h}$ of treatment with calcitonin, and the inhibition continued for at least $48 \mathrm{~h}$. If the giant cells were treated with calcitonin for $24 \mathrm{~h}$, then washed with media and incubated with media not containing calcitonin for an additional $24 \mathrm{~h}$, CTR mRNA expression was restored. Similarly, CTR mRNA expression was decreased by calcitonin in osteoclast-like MNC, and their more differentiated precursors formed in vitro (Fig. 4 B). CTR mRNA expression in either cells was inhibited after incubation with calcitonin for $24 \mathrm{~h}$, but recovered $24 \mathrm{~h}$ after calcitonin was removed from the media (Fig. $4 \mathrm{~B}$ ).

To determine if the decrease in CTR mRNA expression was associated with decreased calcitonin receptor activity, we pretreated giant cells (Fig. 5) or marrow-derived MNC (data not shown ) with calcitonin for $24 \mathrm{~h}$ and tested cAMP production in response to calcitonin in those cells. Pretreatment with calcitonin for $24 \mathrm{~h}$ significantly decreased cAMP production to $\sim 45 \%$ of control values $(P<0.00001$, Fig. 5$)$. The average amount of cAMP produced in response to calcitonin in cultures not pretreated with calcitonin was $634 \pm 173 \mathrm{fmol} / 10^{5}$ cells plated.

\section{Discussion}

In the present study, we used RT-PCR of calcitonin receptor mRNA to study the regulation of CTR mRNA expression in cells in the osteoclast lineage. We showed that CTR mRNA can be detected in RNA samples from osteoclast-like giant cells from osteoclastomas, and that CTR mRNA is expressed in more differentiated mononuclear MNC precursors and osteoclast-like MNC formed in vitro from human bone marrow. In contrast, CTR mRNA expression was not detected in macrophage polykaryons or peripheral blood monocytes. These data support our previous findings that these 23c6-positive MNC formed in human bone marrow and their mononuclear precursors express CTR as detected by $\mathrm{I}^{125}$-salmon calcitonin autoradiography (7). 
A

TIME (h)

06612122424484848 C

CALCITONIN

- . + + . + + + +/

CTR

(317 bp)

$\beta$-ACTIN

(190 bp)

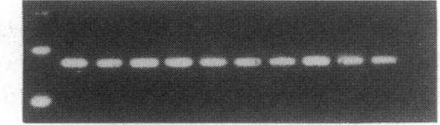

B

TIME (h)
CALCITONIN
B

CTR

(317 bp)

\section{$\beta$-ACTIN \\ (190 bp)}

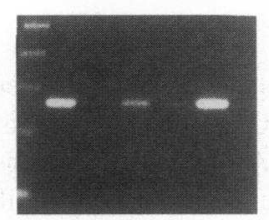

Figure 4. Effects of calcitonin on calcitonin receptor mRNA expression in giant cells from osteoclastomas $(A)$ and mononuclear precursors for osteoclast-like MNC $(B)$. (A) 123-bp ladder is shown on far left; RNA from 23c6-positive cells from osteoclastomas at the indicated time points after incubation with (+) or without (-) calcitonin. One sample was treated with calcitonin for $24 \mathrm{~h}$, then washed and incubated without calcitonin for an additional $24 \mathrm{~h}(48,+/-)$. C, no RNA. (B) 123-bp ladder is shown on far left; $23 \mathrm{c} 6(+) \mathrm{MNC}$ precursors at the indicated time points after incubation with $(+)$ or without $(-)$ calcitonin. One sample was treated with calcitonin for $24 \mathrm{~h}$, then washed and incubated without calcitonin for an additional $24 \mathrm{~h}(48 \mathrm{~h},+/-)$. C, no RNA. Cell preparation was as described in Methods. After cells were incubated in $\alpha$-MEM-10\% FCS with or without calcitonin for the indicated times, RNA was extracted from $10^{4}$ cells, reverse transcribed, and amplified with the primers for CTR or $\beta$-actin. Similar results were seen in three independent experiments.

Our findings that CTR mRNA could not be detected in monocytes or macrophage polykaryons is in contrast to data from others who reported that rat macrophage polykaryons express CTR (30). These differences might be due to variations in culture conditions, or that rat alveolar macrophages differ from human peripheral blood macrophages. Our studies further suggest that differentiation of immature human CFU-GM-derived mononuclear precursor cells to the osteoclast lineage requires $7 \mathrm{~d}$ of exposure to $1,25-(\mathrm{OH})_{2} \mathrm{D}_{3}$.

Loss of calcitonin responsiveness after prolonged administration of calcitonin to patients or animals has been termed the calcitonin "escape phenomenon"' (31). This phenomenon has

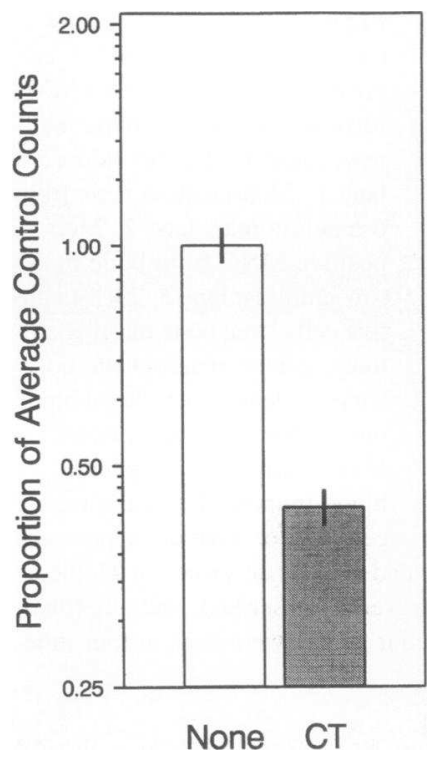

been ascribed to secondary hyperparathyroidism (32) and formation of neutralizing antibodies to calcitonin (15). However, in vitro cultures have shown that osteoclasts lose responsiveness to calcitonin (33-35), and in rat bone or mouse calvaria, the inhibitory effect of calcitonin on bone resorption lasts only 48-96 h $(33,34)$. In isolated osteoclasts, calcitonin induced immediate quiescence and gradual contraction of osteoclasts, as well as inhibition of bone resorption. After 4-8 h, osteoclasts regained cytoplasmic motility and resumption of bone resorption (35). These data suggest a direct effect of calcitonin on osteoclasts.

Downregulation of CT receptors also been reported in mouse calvariae, human carcinoma cell lines, and rat kidney cells $(34,36-38)$, and internalization of CTR and necessity of new protein synthesis for new receptor formation has been reported in a human breast cancer cell line (36). However, the "escape phenomenon" cannot be explained solely on receptor internalization, because many other receptors such as the insulin receptor also are internalized (38), and forskolin, an adenylate cyclase activator, induced similar effects in osteoclasts, including the "escape phenomenon" and inhibition of bone resorption (39). Furthermore, inhibition of DNA synthesis in rodent organ cultures can block calcitonin escape (40). Another possible explanation for the "escape phenomenon"' is that phosphorylation of the intracellular region of the receptor results in desensitization of the intracellular signaling pathway (41).

In the present study, we found that calcitonin treatment of osteoclast-like giant cells from osteoclastomas and osteoclastlike MNC formed in vitro, as well as mononuclear MNC precursors, for $\geq 12 \mathrm{~h}$ decreased CTR mRNA expression. These results were not due to the RNA being degraded in these samples since expression of TRAP and actin mRNA could be detected in the samples. These data suggest that inhibition of CTR gene expression is a potential mechanism to explain calcitonin escape. Inhibition of CTR mRNA expression cannot explain early escape of osteoclasts (4-8 h) from calcitonin, but it might be responsible in part for the continued escape after $12 \mathrm{~h}$.

Other hormones can also downregulate expression of mRNA for their receptors. For example, estrogen and androgens can decrease expression of their respective receptor mRNAs $(42,43)$. These data suggest that hormone downregulation of 
receptor mRNA expression may be a common mechanism that permits cells to "escape" the effects of these hormones.

\section{Acknowledgments}

The authors wish to thank G. R. Mundy and D. H. Boldt for critical review of the manuscript, Tazuko Hymer for technical assistance, V. J. Reddy for preparation of purified giant cells, and Bibi Cates for excellent preparation of the manuscript.

This work was supported by Research Funds from the Veterans Administration and grants AR-39539 and AR-41336 from the National Institute of Arthritis and Musculoskeletal and Skin Diseases, grant AM35188 from the National Institute of Diabetes, Digestive and Kidney Disease, and grants CA-40035 and P30CA54174 from the National Cancer Institute.

\section{References}

1. Nicholson, G. C., J. M. Moseley, P. M. Sexton, F. A. O. Mendelsohn and T. J. Martin. 1986. Abundant calcitonin receptors in isolated rat osteoclasts. Biochemical and autoradiographic characterization. J. Clin. Invest. 78:355-360.

2. Nicholson, G. C., M. A. Horton, P. M. Sexton, J. M. Moseley, B. E. Kemp, J. A. S. Pringle, and T. J. Martin. 1987. Calcitonin receptors of human osteoclastoma. Horm. Metabol. Res. 19:585-589.

3. Bouizar, Z., W. H. Rostene, and G. Milhaud. 1987. Downregulation of rat kidney calcitonin receptors by salmon calcitonin infusion evidenced by autoradiography. Proc. Natl. Acad. Sci. USA. 84:5125-5128.

4. Findlay, D. M., M. DeLuise, V. P. Michelangeli, M. Ellison, and T. J. Martin. 1980. Properties of a calcitonin receptor and adenylate cyclase in BEN cells a human cancer cell line. Cancer Res. 40:1311-1317.

5. Findlay, D. M., V. P. Michelangeli, J. M. Moseley, and T. J. Martin. 1981. Calcitonin binding and deregulation by two cultured human breast cancer cell lines (MCF7 and T47D). J. Biochem. (Tokyo). 196:513-520.

6. Marx, S. J., G. D. Aurbach, J. R. Gavin, and D. W. Buell. 1974. Calcitonin receptors on cultured human lymphocytes. J. Biol. Chem. 249:6812-6816.

7. Kurihara, N., S. Gluck, and G. D. Roodman. 1990. Sequential expression of phenotype markers for osteoclasts during differentiation of precursors for multinucleated cells formed in long-term human marrow cultures. Endocrinology. 127:3215-3221.

8. Takahashi, N., T. Akatsu, T. Sasaki, G. C. Nicholson, J. M. Moseley, T. J. Martin, and T. Suda. 1988. Induction of calcitonin receptors by lalpha, 25dihydroxy vitamin $D_{3}$ in osteoclast-like multinucleated cells formed from mouse bone marrow cells. Endocrinology. 123:1504-1510.

9. Hattersley, G., and T. J. Chambers. 1989. Calcitonin receptors as markers for osteoclastic differentiation: correlation between generation of bone-resorptive cells and cells that express calcitonin receptors in mouse bone marrow cultures. Endocrinology. 125:1606-1612.

10. Chambers, T. J., P. M. J. McSheehy, B. M. Thomson, and K. Fuller. 1985 The effect of calcium-regulating hormones and prostaglandins on bone resorption by osteoclasts disaggregated from neonatal rabbit bones. Endocrinology. 60:234239.

11. Murrills, R. J., E. Shane, R. Lindsay, and D. W. Dempster. 1989. Bone resorption by isolated human osteoclasts in vitro: effects of calcitonin. J. Bone Miner. Res. 4:259-268.

12. Mundy, G. R., R. Wilkinson, and D. A. Heath. 1984. Comparative study of medical therapy for hypercalcemia of malignancy. Am. J. Med. 74:421-437.

13. Wilkinson, R. 1984. Treatment of hypercalcemia associated with malig nancy. Br. Med. J. 280:812-813.

14. Benstock, M. L., and G. R. Mundy. 1980. Effect of calcitonin and glucocorticoids in combination on the hypercalcemia of malignancy. Ann. Intern. Med. 93:269-272.

15. Singer, F. R., R. S. Fredericks, and C. Minkin. 1980. Salmon calcitonin therapy for Paget's disease of bone. Arthritis Rheum. 23:1148-1154.

16. Gorn, A. H., H. Y. Lin, M. Yamin, P. E. Auron, M. R. Flannery, D. R. Tapp, C. A. Manning, H. F. Lodish, S. M. Krane, and S. R. Goldring. 1992. Cloning, characterization, and expression of a human calcitonin receptor from an ovarian carcinoma cell line. J. Clin. Invest. 90:1726-1735.

17. MacDonald, B. R., N. Takahashi, L. M. McManus, J. Holahan, G. R Mundy, and G. D. Roodman. 1987. Formation of multinucleated cells that respond to osteotropic hormones in long-term human bone marrow cultures. Endocrinology. 120:2326-2333.

18. Kukita, T., L. M. McManus, M. Miller, C. Civin, and G. D. Roodman 1989. Osteoclast-like cells formed in long-term human bone marrow cultures express a similar surface phenotype as authentic osteoclasts. Lab. Invest. 60:532538.
19. Takahashi, N., T. Kukita, B. R. MacDonald, A. Bird, G. R. Mundy, L. M. McManus, M. Miller, A. Boyde, S. J. Jones, and G. D. Roodman. 1989. Osteoclast-like cells form in long-term human bone marrow but not in peripheral blood cultures. J. Clin. Invest. 83:543-550.

20. Pfeilschifter, J., C. Chenu, A. Bird, G. R. Mundy, and G. D. Roodman 1989. Interleukin-1 and tumor necrosis factor stimulate the formation of human osteoclast-like cells in vitro. J. Bone Miner. Res. 4:113-118.

21. Kurihara, N., C. Civin, M. Miller, and G. D. Roodman. 1990. Identification of committed mononuclear precursors for osteoclast-like cells formed in longterm human marrow cultures. Endocrinology. 126:2733-2741.

22. Davis, J., J. Warwick, N. Totty, R. Philip, M. Helfrich, and M. Horton. 1989. The osteoclast functional antigen, implicated in the regulation of bone resorption, is biochemically related to the vitronectin receptor. J. Cell Biol. 109:1817-1826.

23. Osaki, Y., S. Takahashi, T. Scarcez, A. Demulder, T. Nishihara, R. Williams, and G. D. Roodman. 1992. Evidence for an autocrine/paracrine role for interleukin- 6 in bone resorption by giant cells from giant cell tumors of bone. Endocrinology. 131:2229-2234.

24. Chirgwin, D. W., A. E. Przybyla, R. J. MacDonald, and W. J. Rutter 1979. Isolation of biologically active ribonucleic acid from sources enriched in ribonucleases. Biochemistry. 18:5294-5299.

25. Lord, D. K., N. C. P. Cross, M. A. Bevilacqua, S. H. Rider, P. A. Gorman, A. V. Graves, D. W. Moss, D. Sheer, and T. M. Cox. 1990. Type 5 acid phosphatase. Sequence, expression and chromosomal localization of a differentiationassociated protein of the human macrophage. Eur. J. Biochem. 189:287-293.

26. Ng, S. Y., P. Gunning, R. Eddy, P. Ponte, J. Leavitt, T. Shows, and L. Kedes. 1985. Evolution of the functional human beta-actin gene and its multipseudogene family: conservation of noncoding regions and chromosomal dispersion of pseudogenes. Mol. Cell. Biol. 5:2720-2732.

27. Gutierrez, G. E., G. R. Mundy, R. Derynck, E. R. Hewlett, and M. S Katz. 1987. Inhibition of parathyroid hormone-responsive adenylate cyclase in clonal osteoblast-like cells by transforming growth factor alpha and epidermal growth factor. J. Biol. Chem. 262:15845-15850.

28. Salomon, Y., S. Londos, and M. Rodbell. 1974. A highly sensitive adenylate cyclase assay. Anal. Biochem. 58:541-548.

29. Alcantara, O., Reddy, S. V., Roodman, G. D., and D. H. Boldt. 1994 Transcriptional regulation of the tartrate-resistant acid phosphatase (TRAP) gene by iron. Biochem. J. 298(2):421-425.

30. Vignery, A., M. J. Raymond, H. Y. Qian, F. Wang, and S. A. Rosenzweig. 1991. Multinucleated rat alveolar macrophages express functional receptors for calcitonin. Am. J. Physiol. 261:F1026-1032.

31. Heersche, J. N. M. 1992. Calcitonin effects on osteoclastic resorption: the 'escape phenomenon' revisited. Bone Miner. 16:174-177.

32. Glajchen, N., S. Thomas, P. Jowell, S. Epstein, F. Ismali, and M. Fallon 1990. The effect of high dose salmon calcitonin on bone mineral metabolism in the normal rat. Calcif. Tissue Int. 46:28-32.

33. Friedman, J., W. Y. W. Au, and L. G. Raisz. 1968. Response of fetal rat bone to thyrocalcitonin in tissue culture. Endocrinology. 82:149-156.

34. Tashjian, A. M., D. R. Wright, J. L. Ivey, and A. Pont. 1978. Calcitonin binding sites in bone: relationships to biological response and escape. Recent Prog. Horm. Res. 34:285-334.

35. Kanehisa, J. 1989. Time course of "escape" from calcitonin-induced inhibition of motility and resorption of disaggregated osteoclasts. Bone. 10:125129.

36. Findlay, D. M., and T. J. Martin. 1984. Relationship between internalization and calcitonin-induced receptor loss in T47D cells. Endocrinology. 115:7883.

37. Bouizar, Z., W. H. Rostene, and G. Milhaud. 1987. Down-regulation of rat kidney calcitonin receptors by salmon calcitonin infusion evidenced by autoradiography. Proc. Natl. Acad. Sci. USA. 84:5125-5128.

38. Findlay, D. M., L. V. P. Michelangeli, and T. J. Martin. 1981. Independent down-regulation of insulin and calcitonin receptors on a human tumor cell line J. Endocrinol. 88:271-281.

39. Lerner, U. H., M. Ransjo, K. Klaushofer, H. Horandner, O. Hoffmann, E. Czerwenka, K. Koller, and M. Peterlik. 1989. Comparison between the effects of forskolin and calcitonin on bone resorption and osteoclast morphology in vitro. Bone. 10:377-387.

40. Krieger, N. S., R. S. Feldman, and A. H. Tashjian Jr. 1982. Parathyroid hormone and calcitonin interactions in bone: irradiation-induced inhibition of escape in vitro. Calcif. Tissue Int. 34(2):197-203.

41. Liggett, S. B. 1991. Desensitization of the beta-adrenergic receptor: distinct molecular determinants of phosphorylation by specific kinases. Pharmacol. Res. 24, Suppl. 1:29-41.

42. Berthois, Y., X. F. Dong, M. Roux-Dossetto, and P. M. Martin. 1990 Expression of estrogen receptor and its messenger ribonucleic acid in the MCF7 cell line: multiparametric analysis of its processing and regulation by estrogen Mol. Cell. Endocrinol. 74(1):11-20.

43. Lin, M. C., J. Rajfer, R. S. Swerdloff, and N. F. Gonzalez-Cadavid. 1993 Testosterone down-regulates the levels of androgen receptor mRNA in smooth muscle cells from the rat corpora cavernosa via aromatization to estrogens. $J$. Steroid Biochem. Mol. Biol. 45(5):333-343. 